\title{
The Need for Awareness of Drinking Water Loss Reduction for Sustainable Water Resource Management in Rwanda
}

\author{
Fidele Karamage ${ }^{1,2,3}$, Chi Zhang1 ${ }^{*}$, Felix Ndayisaba ${ }^{1,2,3}$, Lamek Nahayo ${ }^{1,2,3}$, \\ Alphonse Kayiranga, ${ }^{1,2,3}$, James Kehinde Omifolajii,2, Hua Shao1, Alice Umuhoza", \\ Jean Baptiste Nsengiyumva1,2,5, Tong Liu6
}

\author{
${ }^{1}$ State Key Laboratory of Desert and Oasis Ecology, Xinjiang Institute of Ecology and Geography, Chinesee Academy of Sciences, \\ Urumqi, China \\ ${ }^{2}$ University of Chinese Academy of Sciences, Beijing, China \\ ${ }^{3}$ University of Lay Adventists of Kigali, Kigali, Rwanda \\ ${ }^{4}$ College of Science and Technology, University of Rwanda, Kigali, Rwanda \\ ${ }^{5}$ Ministry of Disaster Management and Refugee Affairs (MIDIMAR), Kigali, Rwanda \\ ${ }^{6}$ College of Life Science, Shihezi University, Shihezi, China \\ Email: ${ }^{\star z c @ m s . x j b . a c . c n ~}$
}

How to cite this paper: Karamage, F., Zhang, C., Ndayisaba, F., Nahayo, L., Kayiranga, A., Omifolaji, J.K., Shao, H., Umuhoza, A., Nsengiyumva, J.B. and Liu, T. (2016) The Need for Awareness of Drinking Water Loss Reduction for Sustainable Water Resource Management in Rwanda. Journa of Geoscience and Environment Protection, 4, 74-87.

http://dx.doi.org/10.4236/gep.2016.410005

Received: September 20, 2016

Accepted: October 23, 2016

Published: October 26, 2016

Copyright $\odot 2016$ by authors and Scientific Research Publishing Inc. This work is licensed under the Creative Commons Attribution International License (CC BY 4.0).

http://creativecommons.org/licenses/by/4.0/

\section{(c) (i) Open Access}

\begin{abstract}
Drinking water loss or Non-Revenue Water (NRW) threatens the financial viability of water utilities and sustainable natural water resource management. However, little attention has been paid to quantitative assessment of the spatial distribution of water losses in Rwanda. Therefore, this study focused on the magnitude of water losses, the associated environmental and socio-economic consequences, as well as the potential benefits from water loss reduction in Rwanda. Based on water usage records from the Water and Sanitation Corporation (WASAC) of Rwanda, NRW was calculated for 15 WASAC branches and Provinces, from July 2013 to June 2014, by using the International Water Association (IWA) standard water balance approach. The results highlight an annual NRW of $16,502,198$ or $41 \%$ of the total water produced, inducing a revenue loss of US\$ $8,713,156$. In 14 of the 15 WASAC water branches and all Rwandan provinces, the NRW ratios exceed the NRW threshold (10\%) recommended by the American Water Works Association (AWWA). Because of the lost revenue, the water facilities may not expand quickly enough to meet the demands of the rapidly growing population. The suggested $50 \%$ reduction in NRW would provide additional $8,251,100 \mathrm{~m}^{3}$ of treated water yearly, enough to serve extra 41,925 households or irrigate 661 ha of cropland and save US\$4,356,579, which would reduce the financial gap in Rwanda's National Water Improvement Project by more than $24 \%$.
\end{abstract}




\section{Keywords}

Non-Revenue Water, Water Loss Reduction, Sustainability, WASAC, Rwanda

\section{Introduction}

Water is an indispensable natural resource which directly affects economic and social development [1]. Drinking water demands are tremendously increasing with galloping demographic pressure and economic development [2]. In the middle of this century, water shortage will affect 2 to 7 billion people [3]. Despite this, water management and conservation practices are not adequate enough to address this incremental challenge worldwide. The total cost of water utilities caused by Non-Revenue Water (NRW) worldwide was estimated at US\$ 141 billion per year, with one third of it occurring in the developing countries where about 45 million cubic meters, enough to serve nearly 200 million people, are lost through daily leakage in water distribution networks. In addition, nearly 30 million cubic meters are delivered every day to customers, but are not invoiced because of pilferage, employees' corruption and poor metering [4]. The worldwide water loss average is estimated at $30 \%$, resulting in the same portion of energy loss [5] [6]. Moreover, the water losses enhance the environmental burden resulting from extra water withdrawals [7] [8]. Meeting the rapidly growing water demands in megacities often means sacrificing the environment, thus leading to water quality degradation, ecosystem damage, and/or unsustainable water use such as groundwater depletion and salt water intrusion [9] [10].

The American Water Works Association (AWWA) Leak Detection and Accountability Committee in 1996 recommended $10 \%$ as the upper limit for water loss or NRW [11]. Although it is not feasible to eliminate all NRW in a water utility, reducing by half the current levels of losses in developing countries appears to be a realistic target. It could generate an estimated additional US $\$ 2.9$ billion in cash every year for the water sector (from both increased revenues and reduced costs) and serve an additional 90 million people without any new investments in production facilities nor drawing further on scarce water resource [4]. For example, most Public-Private Partnerships (PPP) projects for Urban Water Utilities reduce water losses in the Sub-Saharan African countries significantly, where Gabon, Niger, and Senegal have achieved NRW levels below 20 percent during at least two years of operation [12]. Benefits of the water loss management encompass rapid improvements of the financial-economic viability of water utilities (maximize revenues and minimize costs of investments, operations and maintenance of pipe networks), environmental protection (maximize water savings), public health protection (maximize quality water), technically acceptable level of service (maximize water supply reliability) and socioeconomic aspects (maximize affordability of water) [5] [13] [14].

Watershed is an ideal unit for planning, development and management of land and water resources [15] [16] [17] [18]. However, lack of management of soil erosion by 
water from watersheds in Rwanda [19] [20] threatens normal recharge of groundwater [21]. Soil erosion caused by land reclamation also affects the ground water quality in Rwanda [22]. The increased demands for commercial agriculture will also place significant pressures on water resource management. Moreover, the government of Rwanda aims to expand the irrigated cropland by 100,000 ha, which will put enormous stress on the freshwater resource in the country [23]. In addition, the water usage by the energy sector is increasing rapidly, as Rwandan authorities aim to increase energy capacity from $35 \mathrm{MW}$ to $563 \mathrm{MW}$ between 2000 and 2017 [24]. The agricultural water supply was negatively affected by water usage for hydropower production [25]. Assumptions about future climate and water use predicted the water scarcity problem in Southern and Eastern African countries including Rwanda because of increasing population and improved living standards [26].

Notwithstanding the widely underscored water losses in Rwanda, few reports highlighted the magnitude of losses and little to no attention was paid to quantitative assessment of spatial distribution of water losses in Rwanda. Therefore, this study focused on the magnitude of NRW, the associated environmental and socioeconomic consequences, as well as the potential benefits from water loss reduction in Rwanda. Specifically, this study aims to 1) estimate the levels of drinking water losses, 2) discuss their financial costs and 3) estimate the potential benefits if the current water losses are reduced by $50 \%$.

\section{Materials and Methods}

\subsection{Description of the Study Area}

Rwanda (Figure 1) is a landlocked country with the surface area of $26,338 \mathrm{~km}^{2}$, located in the Great Lakes Region of East-central Africa [19], exactly midway between Cape Town and Cairo in Egypt, the country shares borders with Uganda to the North, Burundi to the South, Tanzania to the East and the Democratic Republic of the Congo (DRC) to the West [27]. The natural water resources consisting of wetlands of Rwanda, composed of marshlands, lakes, rivers and streams, cover about $14.9 \%$ of the national territory. Rwanda has a hilly and mountainous relief with an altitude ranging from 900 $\mathrm{m}$ to $4507 \mathrm{~m}$ with a tropical temperate climate. The average annual temperature ranges between $16^{\circ} \mathrm{C}$ and $20^{\circ} \mathrm{C}$. Rwandan soils are naturally fragile, resulting from the physico-chemical alteration of basic schistose, quartzite, gneissic, granite and volcanic rocks [28]. The average precipitation is $1212 \mathrm{~mm} /$ year, and the long-term total annual renewable water resource is $13.3 \mathrm{~km}^{3} /$ year [29]. Rwanda is one of the most densely populated countries in Africa with a population density of 470.6 per $\mathrm{km}^{2}$ in 2015 [30]. The estimated Rwandan population was about 12 million in 2015 with $28.81 \%$ urban population [31] and an annual population growth rate of 2.4 [32]. This population is expected to be around 17 million in 2030 with $41.55 \%$ urban population. In 2050 the population will be more than 25 million, and about $52 \%$ of the total population will be residing in urban areas [31]. This study focused on the estimation of NRW and the associated problems in Rwanda, within 15 branches of WASAC namely Kigali City, Mu- 


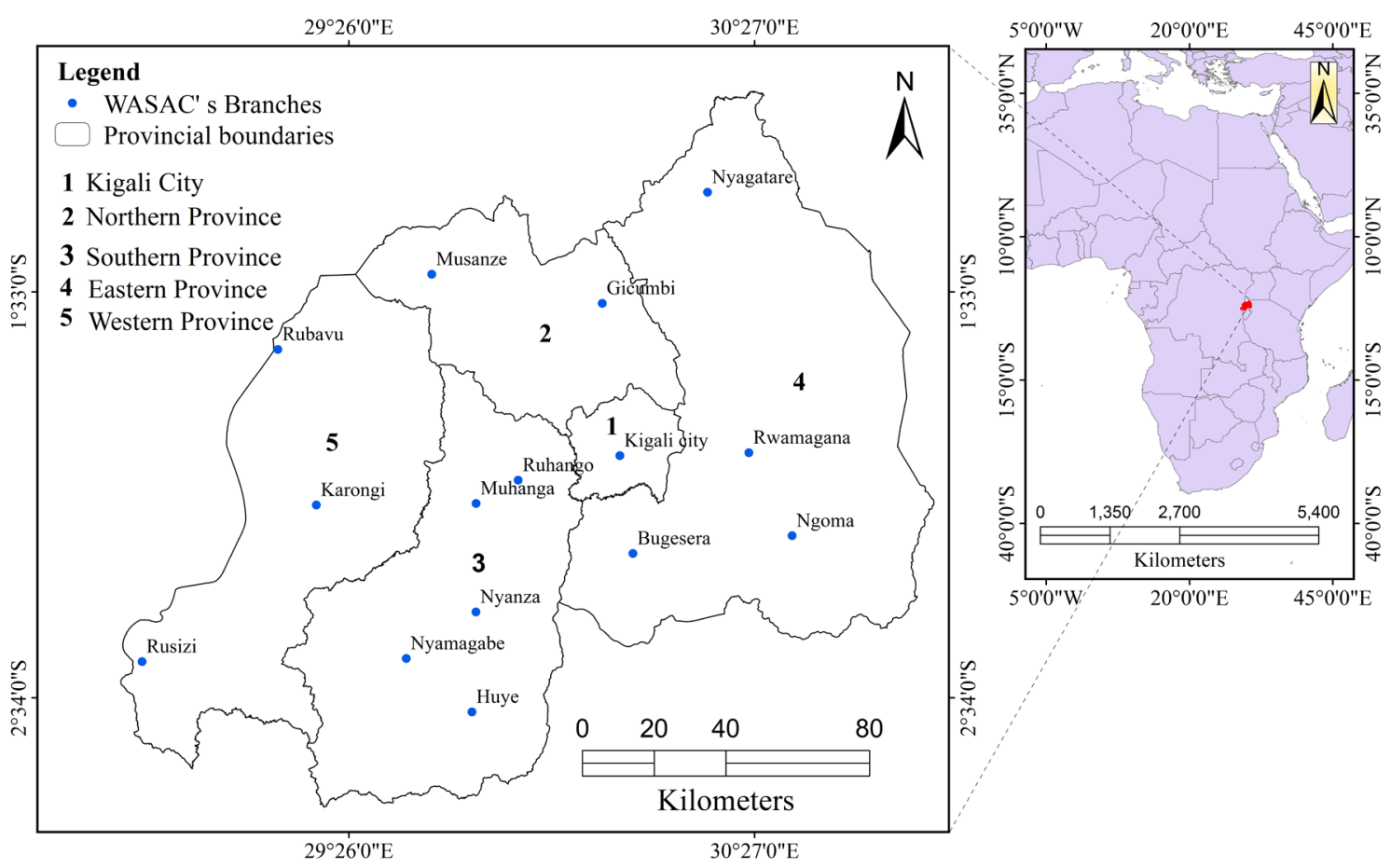

Figure 1. Map showing the location of 15 WASAC's branches in Rwanda.

sanze, Gicumbi, Nyamagabe, Huye, Ruhango, Muhanga, Nyanza, Nyagatare, Rwamagana, Bugesera, Ngoma, Rubavu, Karongi, and Rusizi distributed in the 5 Provinces of Rwanda as shown in Figure 1.

\subsection{Study Design and Data Collection}

Based on the water usage records (Water Produced and Water Billed) acquired from the WASAC, NRW volumes, NRW ratios and their corresponding costs were calculated for the National level (Figure 2), Provincial level (Figure 3(a) and Figure 3(b)), and as well as for the 15 WASAC's branches (Figure 4(a) and Figure 4(b)) for the study periodstarting from July 2013 to June 2014 using Equations (1) and (2).

$$
\begin{aligned}
& \text { NRW }=\text { Water Produced }- \text { Water Billed } \\
& \text { NRW ratio }=(\text { Water Produced }- \text { Water Billed }) / \text { Water Poduced }
\end{aligned}
$$

where: Water Produced = the annual input to a defined part of the water supply system; Water Billed = the annual volume of metered and/or non-metered water taken by registered customers, the water supplier and others authorized to do so. NRW ratio is the difference between the volume of water produced and billed to customers divided by the volume of water produced. This ratio captures the efficiency of both the distribution network (physical losses) and the commercial management (commercial losses related to metering and billing problems) [12]. NRW is also interpreted as a water loss from public water utilities because of poor water distribution network facilities and management, often caused by corrosive environments, soil movement, poor construction standards, and fluctuation of water pressure, excessive traffic loads and vibration. 


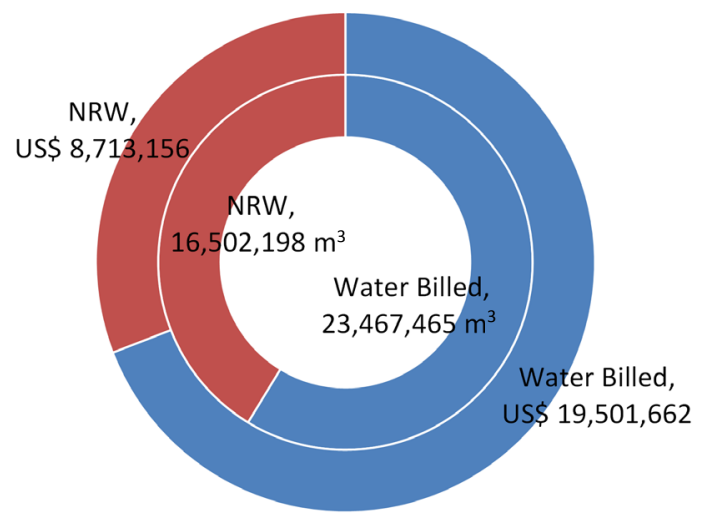

Figure 2. Rwanda's total water balance and its costs, July 2013 - June 2014.

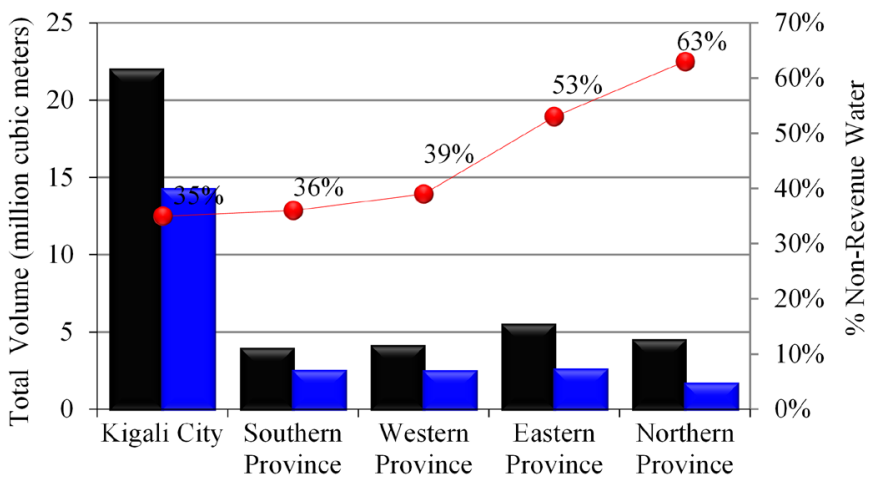

Total Water Produced $\left(\mathrm{m}^{3}\right)$

Water Billed $\left(\mathrm{m}^{3}\right) \quad-\% \mathrm{NRW}$

(a)

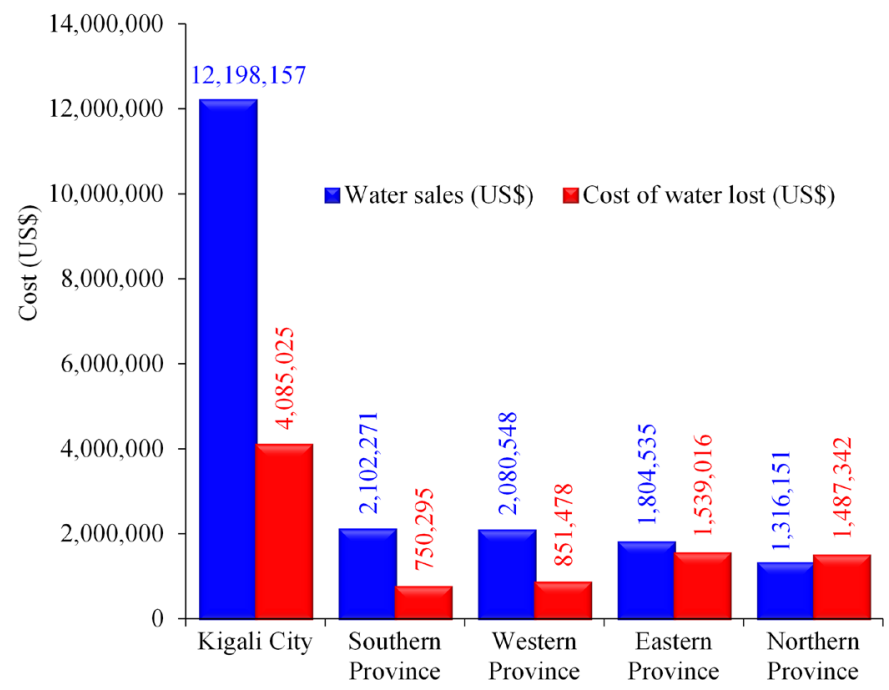

(b)

Figure 3. (a) Water balance for the provinces of Rwanda, July 2013 June 2014; (b) Water sales and losses for the provinces of Rwanda, July 2013 - June 2014. 


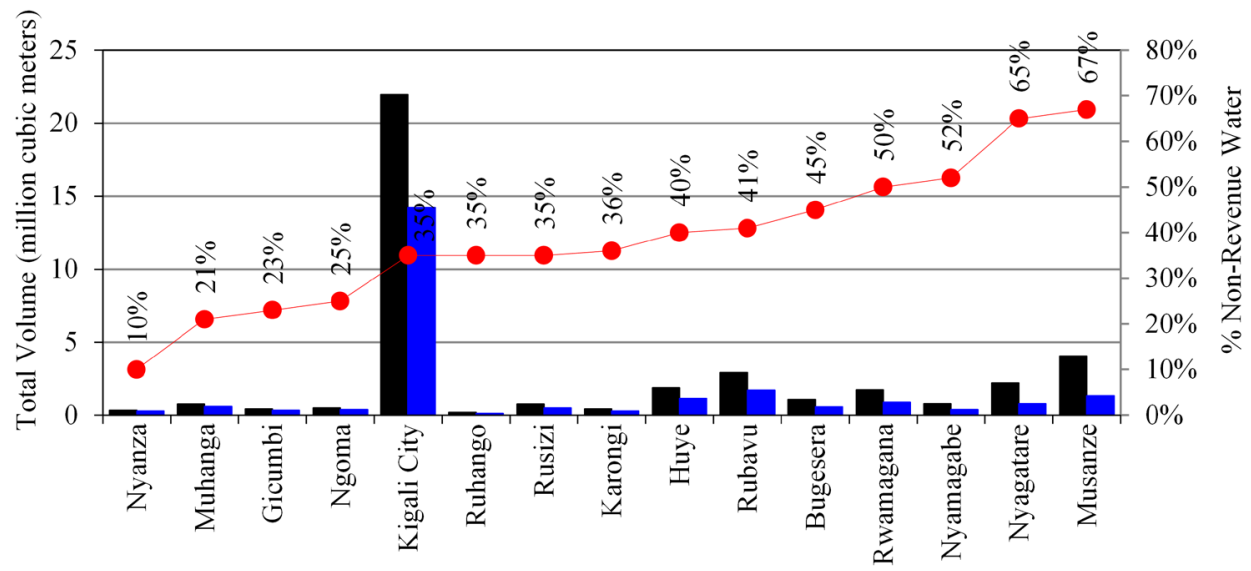

WASAC'S Branches

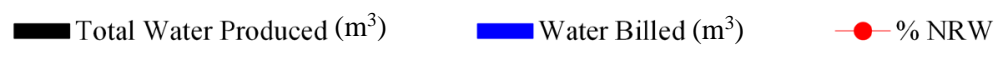

(a)

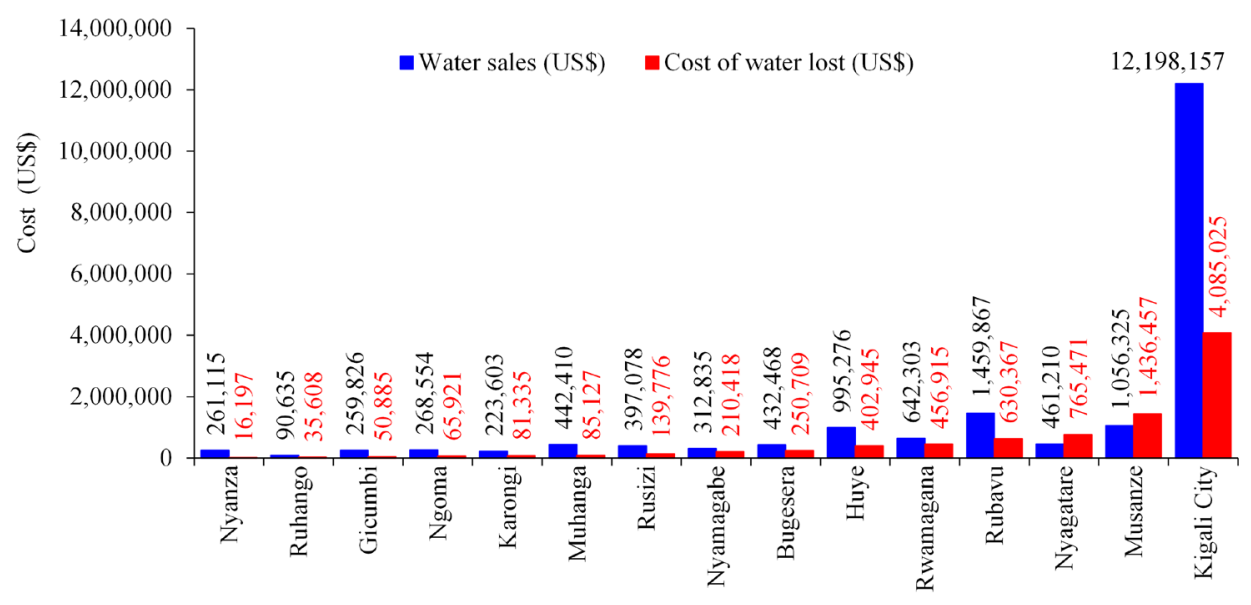

WASAC' s Branches

(b)

Figure 4. (a) Water balance for the 15 WASAC's branches, July 2013 - June 2014. (b) Water sales and losses for the 15 WASAC's branches, July 2013 - June 2014.

On account of these causes, water losses could occur at different level components, such as transmission, distribution and service connection pipes, joints, valves, fire hydrants, storage tanks and reservoirs [33] [34] [35]. The cost of NRW was calculated multiplying US $\$ 0.528$ per $\mathrm{m}^{3}$ with the volume of water lost based on the following criteria:

- An average exchange rate of the US\$1 equals RWF671.019 according to the historical exchange rates observed on the OANDA's website (http://www.oanda.com/) [36] for the study period from July 2013 to June 2014.

- Rwanda average monthly water consumption was $16.4 \mathrm{~m}^{3} /$ household [37], meaning the average annual water consumption in meter cubes per household was $16.4 \mathrm{~m}^{3}$ times 12 (number of months), which isequal to $196.8 \mathrm{~m}^{3}$. The tariff of this con- 
sumption category was RWF 354 (US\$0.528) per $1 \mathrm{~m}^{3}$ including the V.A.T. (value added tax) at $18 \%$ [38].

Then, the potential benefits were estimated in the Revenue, household water supply and cropland irrigation from 50\% water loss reduction in Rwanda:

- Expected revenues equal $50 \%$ of water loss reduction $\left(\mathrm{m}^{3}\right)$ times US\$ 0.528 (cost of 1 $\left.\mathrm{m}^{3}\right)$.

- Number of households that can benefit from the improved drinking water in Rwanda equals to $50 \%$ of the anticipated water loss reduction $\left(\mathrm{m}^{3}\right)$ over $196.8 \mathrm{~m}^{3}$ per household.

- In Rwanda, the gross irrigation water requirement equals $12,500 \mathrm{~m}^{3} / \mathrm{ha}$ a year [39]. Therefore, the croplands that can be irrigated by the saved water from $50 \%$ of water loss reduction equal to $50 \%$ of saved water $\left(\mathrm{m}^{3}\right)$ over $12,500 \mathrm{~m}^{3}$ per hectare a year.

The Progress towards MDG (Millennium Development Goals) target in the improved water coverage in Rwanda, 1990-2015 (Figure 5) was presented by the official statistical data on trends in drinking water coverage from 1990-2015, as published by the WHO/UNICEF Joint Monitoring Programme (JMP) for Water Supply and Sanitation [40], available on the website (http://www.wssinfo.org/).

\section{Results}

Rwanda faced severe NRW problems at all spatial scales. The results of this study, indicated that the total water supplied in Rwanda was 39,969,663 $\mathrm{m}^{3}$ from July 2013 to June 2014 , of which $41 \%$ was lost. The water losses cost Rwanda US\$ 8,713,156 per year (Figure 2).

On provincial scale, the Northern Province had the highest NRW ratio of $63 \%$. The water loss ratio in the Eastern Province also exceeded 50\%, while Kigali City that had a water loss ratio of $35 \%$ is responsible for $47 \%$ of the total National water loss (Figure $3(a))$, meaning that water loss reduction could significantly improve the efficiency in

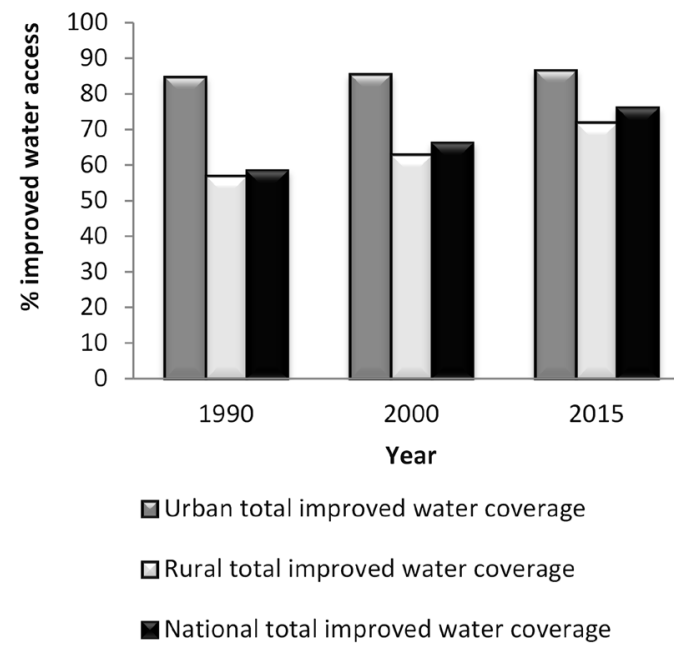

Figure 5. Progress towards MDG target in improved water coverage in Rwanda, 1990-2015. 
drinking water supply in Rwanda. In addition, the costs of water loss are US\$ 4,085,025 in Kigali City, US\$1,487,342 in Northern Province, US\$ 750,295 in Southern Province, US\$ 1,539,016 in Eastern Province and US\$ 851, 478 in Western Province (Figure 3(b)) from July 2013 to June 2014.

Among the 15 WASAC's branches, the NRW ratio ranged from $10 \%$ in Nyanza to $67 \%$ in Musanze (Figure 4(a)). Referring to the benchmark of $10 \%$ tolerable for NRW/ Water Loss [11], 14 WASAC's branches presented water loss ratios beyond the acceptable upper limit with the exception of Nyanza branch. Particular attention should be paid to the Musanze, Nyagatare, Nyamagabe, and Rwamagana branches where more than $50 \%$ of treated water was lost. The lowest cost of water loss was US\$16,197 in Nyanza, while the highest cost was US\$ 4,085,025 in Kigali City (Figure 4(b)).

\section{Discussion}

High levels of water losses created many problems in Rwanda, including poor financial viability for the Water and Sanitation Corporation, water demand deficit, the unfilled gap of improved drinking water accessibility and pressure on natural water resources [41]. Because of financial problems and high levels of NRW, the water facilities did not expand quickly enough to meet the demand of the rapidly growing population. In recent years, the nation's water resources have been threatened by various sources of pollution such as industrial effluents, fertilizers, chemical pesticides, and wastewaters associated with population pressure and unplanned urbanization [42]-[52]. Pressure on water resources has been reported to be among the major environmental problems due to soil erosion [19], deforestation, wetland degradation and pollution [53] [54] [55]. Moreover, the quality of drinking water is threatened by an insufficient maintenance of the current water distribution network [56]. Groundwater remains an unexplored area, apart from a few holes drilled by some projects and a limited number of about 22,000 sources identified in the country. For instance, the daily water demand in 2013 was $90,000 \mathrm{~m}^{3}$ in Kigali, the capital city of Rwanda. The daily production was $64,000 \mathrm{~m}^{3}$, and $42.3 \%$ were NRW, leaving a deficit of $26,000 \mathrm{~m}^{3}$. As a result, the Energy, Water and Sanitation Authority failed to supply the required water to the capital of Rwanda from January 2011 to 30 September 2013 [57].

Similarly, the severe water loss problems affected the financial viability throughout the Sub-Saharan countries and undermined their capacity to expand the coverage of treated water supply [41]. The government of Rwanda recognized the role of water availability for development and adopted the MDG's drinking water with a target of increasing the proportion of the population with access to improved water from $76 \%$ in 1990 to $88 \%$ in 2015 [40]. Although, the national water coverage rose from $58.5 \%$ in 1990 to $76.1 \%$ in 2015 (Figure 5), the MDG drinking water target was not met and there is still inequality between urban and rural water coverage, being driven mainly by population pressures and severe water losses. This national gap of $23.9 \%$ in water supply to meet clean water supply for the total Rwandan population could be reduced by the saved water from water loss reduction. 
Even though it would sound unrealistic to expect water utilities to eliminate all water losses (commercial and physical losses), water losses in developing countries could be reduced by at least $50 \%$ [14]. According to the estimates from this study, a $50 \%$ of water loss reduction in Rwanda would save $8,251,100 \mathrm{~m}^{3}$ per year of treated water that can serve an additional 41,925 households and save US\$4,356,579 (Table 1). As socioeconomic benefits, more people can have access to safe drinking water, which plays an important role in the improvement of their healthcare and stimulates socioeconomic development by reducing the time spent searching for water on a long distance. The government of Rwanda aims to extend the coverage of treated water supply to 0.425 million people per year. This requires an annual capital investment of US\$ 54 million. However, the available financial support for the National Water Coverage Improvement Projects is US\$ 34 million per year (US\$ 32 million from the public investment plus US\$ 2 million from households water billings), leaving a funding gap of US\$ 18 million per year [58]. The anticipated saving of US\$ 4,356,579 from $50 \%$ of water losses reduction reduces the gap by more than $24 \%$ (Table 1 ).

Alternatively, the saved water can be used for irrigation. Irrigated agriculture is dependent on an adequate water supply of usable quality [59]. Rwandan soil and terrain suitable for surface irrigation were estimated at 300,900 ha (11\% of the total country), and 150,000 ha was irrigation potential area within the Nile basin with the total gross irrigation water requirement of $1.88 \mathrm{~km}^{3} /$ year $\left(12,500 \mathrm{~m}^{3} /\right.$ ha every year). The area under irrigation was 2000 ha in 1997 [39]. In this study it can be estimated that if the saved water from $50 \%$ of water loss reduction is used for the cropland irrigation, additional 661 ha area would be under irrigation annually (Table 1). A study on the CrossComparison of Climate Change Adaptation Strategies Across Large River Basins in Europe, Africa and Asia highlighted that adaptation options for Rwanda are land use changes, land management, water and improvement of hydrological forecasting [60]. Water losses reduction can be one of the adaptation policies to climate change; for example in the Eastern Province and the Eastern parts of Nyanza and Gisagara districts in Southern province where high frequency of rainfall deficit, late rainfall onsets, early rainfall cessations, and droughts events became increasingly severe in recent decades [61] [62]. Furthermore, water losses reduction will substantially help to meet the water

Table 1. Benefits from water losses Reduction in Rwanda.

\begin{tabular}{|c|c|c|c|c|}
\hline Provinces & $\begin{array}{l}\text { Suggested } 50 \% \\
\text { of water losses } \\
\text { reduction }\left(\mathrm{m}^{3}\right)\end{array}$ & $\begin{array}{l}\text { Expected revenue from } \\
50 \% \text { of water losses } \\
\text { reduction (US\$) }\end{array}$ & $\begin{array}{c}\text { Number of households } \\
\text { that would have access } \\
\text { to improved water }\end{array}$ & $\begin{array}{c}\text { Cropland that } \\
\text { could be irrigated } \\
\text { (ha/year) }\end{array}$ \\
\hline Kigali City & $3,868,395$ & $2,042,513$ & 19,656 & 309 \\
\hline Northern Province & $1,408,468$ & 743,671 & 7,157 & 113 \\
\hline Southern Province & 710,506 & 375,148 & 3,610 & 57 \\
\hline Eastern Province & $1,457,402$ & 769,508 & 7,405 & 117 \\
\hline Western Province & 806,329 & 425,739 & 4,097 & 65 \\
\hline Total in Rwanda & $8,251,100$ & $4,356,579$ & 41,925 & 661 \\
\hline
\end{tabular}


demand for the growing population in Rwanda.

\section{Conclusion}

Reduction of the drinking water loss is beneficial to any country. This study assessed the Non-Revenue Water in Rwanda from July 2013 to June 2014 and its related environmental and socio-economic challenges. The results indicated that the NRW in the country amounted to $41 \%$ of the total water supplied, accounting a revenue loss of US\$ $8,713,156$. This study suggests a reduction of at least $50 \%$ of the current water losses that would improve the economic and financial viability of water utilities, environmental protection, and public health protection through water quality control, maximize water supply reliability and maximize affordability of water and as well, energy savings in Rwanda.

\section{Acknowledgements}

The authors would like to thank the anonymous reviewers and the Editor whose constructive comments and suggestions have helped improve the quality of this manuscript. This study was supported by the National Natural Scientific Foundation of China (\#U1503301) and the National Basic Research Programs of China (\#2014CB954204).

\section{References}

[1] Coulibaly, N., Coulibaly, L., Sengupta, S., Savanna, I. and Umesh, B. (2013) Use of MultiCriteria Evaluation and Geographic Information Systems for Water Resources Management: Case of Bâoulé Basin (North-West of Côte d'ivoire). Indian Journal of Science and Technology, 6, 4035-4040.

[2] Zhang, Q., Xu, C.Y. and Yang, T. (2009) Variability of Water Resource in the Yellow River Basin of Past 50 Years, China. Water Resources Management, 23, 1157-1170. http://dx.doi.org/10.1007/s11269-008-9320-2

[3] Lambert, A. and Hirner, W. (2000) Losses from Water Supply Systems: Standard Terminology and Recommended Performance Measures. IWA Blue Pages.

[4] Kingdom, B., Liemberger, R. and Marin, P. (2006) The Challenge of Reducing Non-Revenue Water (NRW) in Developing Countries. How the Private Sector Can Help: A Look at performance-Based Service Contracting. Watersupply and Sanitation Sector Board Discusion Paper Series, 8, 1-52.

[5] Alkasseh, J.M., Adlan, M.N., Abustan, I., Aziz, H.A. and Hanif, A.B.M. (2013) Applying Minimum Night Flow to estimate Water Loss Using Statistical Modeling: A Case Study in Kinta Valley, Malaysia. Water Resources Management, 27, 1439-1455.

http://dx.doi.org/10.1007/s11269-012-0247-2

[6] Kanakoudis, V., Tsitsifli, S. and Papadopoulou, A. (2012) Integrating the Carbon and Water Footprints' Costs in the Water Framework Directive 2000/60/EC Full Water Cost Recovery Concept: Basic Principles towards Their Reliable Calculation and Socially just Allocation. Water, 4, 45-62. http://dx.doi.org/10.3390/w4010045

[7] Foster, S. and Chilton, P. (2003) Groundwater: The Processes and Global Significance of Aquifer Degradation. Philosophical Transactions of the Royal Society B: Biological Sciences, 358, 1957-1972. http://dx.doi.org/10.1098/rstb.2003.1380 
[8] Nagara, G., Lam, W.H., Lee, N.C.H., Othman, F. and Shaaban, M.G. (2015) Comparative Swot Analysis for Water Solutions in Asia and Africa. Water Resources Management, 29, 125-138. http://dx.doi.org/10.1007/s11269-014-0831-8

[9] Sun, G., Michelsen, A.M., Sheng, Z., Fang, A.F., Shang, Y. and Zhang, H. (2015) Featured Collection Introduction: Water for Megacities-Challenges and Solutions. JAWRA Journal of the American Water Resources Association, 51, 585-588.

http://dx.doi.org/10.1111/1752-1688.12317

[10] Esteller, M.V. and Diaz-Delgado, C. (2002) Environmental Effects of Aquifer Overexploitation: A Case Study in the Highlands of Mexico. Environmental Management, 29, 266-278. http://dx.doi.org/10.1007/s00267-001-0024-0

[11] Association, A.W.W. (1996) Committee Report: Water Accountability. Journal $A W W A$, 88, 108-111.

[12] Marin, P. (2009) Public-Private Partnerships for Urban Water Utilities: A Review of Experiences in Developing Countries. World Bank Publications Vol. 8. http://dx.doi.org/10.1596/978-0-8213-7956-1

[13] Mutikanga, H.E., Sharma, S.K. and Vairavamoorthy, K. (2011) Multi-Criteria Decision Analysis: A Strategic Planning Tool for Water Loss Management. Water Resources Management, 25, 3947-3969. http://dx.doi.org/10.1007/s11269-011-9896-9

[14] Frauendorfer, R. and Liemberger, R. (2010) The Issues and Challenges of Reducing NonRevenue Water. http://hdl.handle.net/11540/1003

[15] Reddy, K.R., Murthy, R.S. and Patode, R.S. (2013) Thematic Integration Approach for Watershed and Land Management. Indian Journal of Science and Technology, 6, 5380-5385.

[16] Kaiyal, J.C., Singh, R.P., Sharma, S., Das, S.K., Padmanabhan, M.V. and Mishra, P.K. (1995) Field Manual on Watershed Management. Central Research Institute for Dryland Agriculture, Hyderabad, 223.

http://203.200.22.249:8080/jspui/bitstream/2014/11866/1/Filed_manual_on_watershed_ma nagement.pdf

[17] Das, R.K. (2012) Sediment Yield Estimation for Watershed Prioritization: A Remote Sensing Study. Indian Journal of Science and Technology, 5, 2374-2378.

[18] Geena, G. and Ballukraya, P. (2011) Estimation of Runoff for Red Hills Watershed Using SCS Method and GIS. Indian Journal of Science and Technology, 4, 899-902.

[19] Karamage, F., Zhang, C., Ndayisaba, F., Shao, H., Kayiranga, A., Fang, X., Nahayo, L., Muhire Nyesheja, E. and Tian, G. (2016) Extent of Cropland and Related Soil Erosion Risk in Rwanda. Sustainability, 8, 609. http://dx.doi.org/10.3390/su8070609

[20] Karamage, F., Zhang, C., Kayiranga, A., Shao, H., Fang, X., Ndayisaba, F., Nahayo, L., Mupenzi, C. and Tian, G. (2016) USLE-Based Assessment of Soil Erosion by Water in the Nyabarongo River Catchment, Rwanda. International Journal of Environmental Research and Public Health, 13, 835. http://dx.doi.org/10.3390/ijerph13080835

[21] FAO (2016) AQUASTAT Website. Food and Agriculture Organization of the United Nations (FAO).

http://www.fao.org/nr/water/aquastat/countries_regions/Profile_segments/RWA-WR_eng. $\underline{\mathrm{stm}}$

[22] Murekatete, E. (2013) Controls of Denitrification in Agricultural Soils, Wetlands, and Fish Ponds in the Migina Catchment, Rwanda. MSc. Dissertation, Unesco-IHE, Delft.

[23] MINECOFIN (2013) Economic Development and Poverty Reduction Strategy II, 2013-2018: Shaping Our Development.

http://www.minecofin.gov.rw/fileadmin/templates/documents/NDPR/EDPRS_2.pdf 
[24] Hakorimana, C. (2014) Role of Environmental Impact Assessment in Decision Making for Hydropower Projects in Rwanda: Case Study of Rugezi and Mukungwa II Hydropower Projects. Ph.D. Dissertation, UNESCO-IHE, Delft.

[25] Hategekimana, S. (2010) Stakeholders Participation in Wetland Management: The Case Study of Rugezi Wetland, Rwanda. Ph.D. Dissertation, UNESCO-IHE, Delft.

[26] Meigh, J., McKenzie, A. and Sene, K. (1999) A Grid-Based Approach to Water Scarcity Estimates for Eastern and Southern Africa. Water Resources Management, 13, 85-115. http://dx.doi.org/10.1023/A:1008025703712

[27] Oppong, J.R. (2009) Rwanda-Juvenile Literature. I. Title. II. Series. Infobase Publishing, New York.

[28] Twagiramungu, F. (2006) Environmental Profile of Rwanda. Consultancy Report, European Commission, Kigali, Rwanda, 78 p.

http://www.vub.ac.be/klimostoolkit/sites/default/files/documents/rwanda-environmental-p rofile.pdf

[29] FAO (2016) Water Resources.

http://www.fao.org/nr/water/aquastat/water_res/index.stm\#Method

[30] United Nations (2015) World Population Prospects: The 2015 Revision. http://esa.un.org/unpd/wpp/

[31] United Nations (2014) World Urbanization Prospects: The 2014 Revision. https://esa.un.org/unpd/wup/

[32] AFDB (2015) African Statistical Yearbook 2015. http://www.afdb.org/en/knowledge/publications/african-statistical-yearbook/

[33] Amaruddin, H.I., Hassan, R., Amin, N.M. and Malek, N.J.A. (2014) Finite Element Model of Mortise and Tenon Joint Fastened with Wood Dowel Using Kempas Species. In: Hassan, R., Yusoff, M., Ismail, Z., Amin, N.M. and Fadzil, M.A., InCIEC 2013, Springer, Singapore, 3-14. http://dx.doi.org/10.1007/978-981-4585-02-6_1

[34] Ku-Mahamud, K.R., Ishak, W.H.W. and Bakar, M.S.A. (2007) Managing Water Loss for Sustainability of Rural Water Supply. Proceedings of the Rural ICT Development Conference (RICTDC 2007), Sintok, Kedah, 20-21. http://www.wanhussain.com/Pub/Ruhana07b.pdf

[35] Tabesh, M., Yekta, A.A. and Burrows, R. (2009) An Integrated Model to Evaluate Losses in Water Distribution Systems. Water Resources Management, 23, 477-492. http://dx.doi.org/10.1007/s11269-008-9284-2

[36] OANDA (2016) Historical Exchange Rates: OANDA's Currency Calculator Tools Use OANDA Rates. http://www.oanda.com/currency/converter/

[37] Fa, U.M., Nhapi, I., Wali, U. and Banadda, N. (2010) Assessment of Wastewater Management Practices in Kigali City, Rwanda. Open Environmental \& Biological Monitoring Journal, 3, 21-28.

[38] WASAC (2015) Water Tariff. http://www.wasac.rw/

[39] Frenken, K. and Faurès, J.M. (1997) Irrigation Potential in Africa: A Basin Approach. FAO Land and Water Bulletin, Vol. 4, Food \& Agriculture Organization.

[40] WHO/UNICEF (2015) Progress on Sanitation and Drinking Water-2015 Update and MDG Assessment. http://www.wssinfo.org/

[41] WaterAid and DFI (2012) Financing of the Water, Sanitation and Hygiene Sector in Rwanda. http://www.wateraid.org/jp

[42] Thiagarajan, S. and Ganesan, M. (2015) Ammonia Behaviour in Wastewater Reclamation 
by Soil Aquifer Treatment. Indian Journal of Science and Technology, 8, 1-10.

http://dx.doi.org/10.17485/ijst/2015/v8i14/61978

[43] Nitschke, L. and Schüssler, W. (1998) Surface Water Pollution by Herbicides from Effluents of Waste Water Treatment Plants. Chemosphere, 36, 35-41.

http://dx.doi.org/10.1016/S0045-6535(97)00286-5

[44] Sharma, S. and Sharma, P. (2010) Biomonitoring of Aquatic Ecosystem with Concept and Procedures Particular Reference to Aquatic Macro Invertebrates. Journal of American Science, 6, 1246-1255.

[45] Schwarzenbach, R.P., Egli, T., Hofstetter, T.B., Von Gunten, U. and Wehrli, B. (2010) Global Water Pollution and Human Health. Annual Review of Environment and Resources, 35, 109-136. http://dx.doi.org/10.1146/annurev-environ-100809-125342

[46] Kimani, R.W., Mwangi, B.M. and Gichuki, C.M. (2012) Treatment of Flower Farm Wastewater Effluents Using Constructed Wetlands in Lake Naivasha, Kenya. Indian Journal of Science and Technology, 5, 1870-1878.

[47] Pranavam, T.D., Rao, T.V., Punithavathi, L., Karunanithi, S. and Bhaskaran, A. (2011) Groundwater Pollution in the Palar Riverbed near Vellore, Tamil Nadu, India. Indian Journal of Science and Technology, 4, 19-21.

[48] Andrade, F., Aravinda, H. and Puttaiah, E. (2011) Studies on Mangalore Coastal Water Pollution and Its Sources. Indian Journal of Science and Technology, 4, 553-557.

[49] Loganathan, D., Kamatchiammal, S., Ramanibai, R., Santhosh, D.J., Saroja, V. and Indumathi, S. (2011) Status of Groundwater at Chennai City, India. Indian Journal of Science and Technology, 4, 566-572.

[50] Ravichandran, K. and Jayaprakash, M. (2011) Seasonal Variation on Physico-Chemical Parameters and Trace Metals in Groundwater of an Industrial Area of North Chennai, India. Indian Journal of Science and Technology, 4, 646-649.

[51] Ntakirutimana, T., Du, G., Guo, J.S., Gao, X. and Huang, L. (2013) Pollution and Potential Ecological Risk Assessment of Heavy Metals in a Lake. Polish Journal of Environmental Studies, 22, 1129-1134.

[52] Udayalaxmi, G., Himabindu, D. and Ramadass, G. (2010) Geochemical Evaluation of Groundwater Quality in Selected Areas of Hyderabad, A.P., India. Indian journal of Science and Technology, 3, 546-553.

[53] UNEP (2010) Rwanda State of Environment and Outlook: Our Environment for Economic Development. http://www.unep.org/publications/contents/pub_details_search.asp?ID=4089

[54] Habiyaremye, G., Jiwen, G., de la Paix Mupenzi, J. and Balogun, W.O. (2011) Demographic Pressure Impacts on Forests in Rwanda. African Journal of Agricultural Research, 6, 4533-4538.

[55] Nahayo, L., Li, L., Kayiranga, A., Karamage, F., Mupenzi, C., Ndayisaba, F. and Nyesheja, E.M. (2016) Agricultural Impact on Environment and Counter Measures in Rwanda. African Journal of Agricultural Research, 11, 2205-2212. http://dx.doi.org/10.5897/AJAR2016.10899

[56] Bayavuge, A. (2008) GIS-Based Multi-Objective Management of Drinking Water Quality in Intermittent Supplies: The Case of Kigali City, Rwanda. Ph.D. Dissertation, UNESCO-IHE, Delft.

[57] OAG (2014) Performance Audit Report of Water Production and Distribution in Kigali City by EWSA for the Period 1 January 2011-30 September 2013.

http://oag.gov.rw/documents/reports-to-parliament/performance-audit-reports/ 
[58] World Bank (2011) Water Supply and Sanitation in Rwanda: Turning Finance into Services for 2015 and beyond. An AMCOW Country Status Overview. World Bank Group, Washington DC.

http://documents.worldbank.org/curated/en/2011/12/19185590/water-supply-sanitation-rw anda-turning-finance-services-2015-beyond

[59] Alexander, J.J. and Mahalingam, B. (2011) Sustainable Tank Irrigation: An Irrigation Water Quality Perspective. Indian Journal of Science and Technology, 4, 22-26.

[60] Krysanova, V., Dickens, C., Timmerman, J., Varela-Ortega, C., Schlüter, M., Roest, K., Huntjens, P., Jaspers, F., Buiteveld, H. and Moreno, E. (2010) Cross-Comparison of Climate Change Adaptation Strategies across Large River Basins in Europe, Africa and Asia. Water Resources Management, 24, 4121-4160. http://dx.doi.org/10.1007/s11269-010-9650-8

[61] Tschirley, D., Nijhoff, J.J., Arlindo, P., Mwinga, B., Weber, M.T. and Jayne, T.S. (2004) Anticipating and Responding to Drought Emergencies in Southern Africa: Lessons from the 2002-2003 Experience. NEPAD Regional Conference on Successes in African Agriculture, Nairobi, 22-25 November 2004.

https://www.researchgate.net/profile/Michael_Weber13/publication/5180422_Anticipating _and_Responding_to_Drought_Emergencies_in_Southern_Africa_Lessons_from_the_2002 -2003_Experience/links/0fcfd509104b68c5e2000000.pdf

[62] Nabahungu, N. and Visser, S. (2013) Farmers' Knowledge and Perception of Agricultural Wetland Management in Rwanda. Land Degradation \& Development, 24, 363-374. http://dx.doi.org/10.1002/ldr.1133

Submit or recommend next manuscript to SCIRP and we will provide best service for you:

Accepting pre-submission inquiries through Email, Facebook, LinkedIn, Twitter, etc. A wide selection of journals (inclusive of 9 subjects, more than 200 journals)

Providing 24-hour high-quality service

User-friendly online submission system

Fair and swift peer-review system

Efficient typesetting and proofreading procedure

Display of the result of downloads and visits, as well as the number of cited articles Maximum dissemination of your research work

Submit your manuscript at: http://papersubmission.scirp.org/

Or contact gep@scirp.org 